\title{
Customs Regulation of Cross-Border Movement of Goods Containing Intellectual Property Objects in the Context of Eurasian Integration
}

\author{
Olga I. Solodukhina*, Irina V. Minakova, and Anna Baroian \\ Southwest State University, 305040, street 50 years October, 94, Kursk, Russia
}

\begin{abstract}
A condition for the effective integration of Eurasian Economic Union member states economies is creating a set of mechanisms for the use of intellectual property objects in modern circumstances. With significant intellectual potential existing in the EAEU countries, the process of commercialization and use of intellectual property objects is not carried out sufficiently. Considering the main purpose of the Union's functioning, this problem has to be solved comprehensively and consistently. The article presents the main results of study of customs regulation system of goods containing intellectual property objects crossborder movement in the context of Eurasian integration. It is noted that the violation of intellectual property rights occurs not only among competing companies as a plagiarism or industrial espionage, but also within framework of agreements concluded between copyright holders and users of intellectual property rights. The EAEU countries cooperate and organize interaction of authorized bodies also to form a unified system of intellectual property rights protection within the EAEU, SCO, BRICS, as well as the WTO. In order to improve the system of customs control of goods containing intellectual property objects, constant adjustments and modernization of methods for controlling the intellectual property objects movement across the customs border of the EAEU are required to ensure the maximum possible protection of intellectual property holders from illegal actions of third parties. The publication was made within the framework of the state assignment for 2021 No. 0851-2020-0034
\end{abstract}

On the one hand, economic relations expansion in the field of intellectual property has a positive effect on the development of the market information segment, but on the other hand, there is a question about the existence of offenses in this area, including during

\footnotetext{
*Corresponding author : kuznecova_olja@mail.ru
} 
moving goods across the customs border of the EAEU and their subsequent introduction into trade

Violation of intellectual property rights occurs not only among competing companies as a plagiarism or industrial espionage, but also within framework of agreements concluded between copyright holders and users of intellectual property rights. The most common cases of violation of intellectual property rights are:

- export of products created on the basis of an existing original by violation of intellectual property rights;

- production of goods using patented technology, sale of this product, distribution of advertising materials about it, transportation of the product abroad, import into the country, storage of goods, etc.;

- usage of the manufacturing technology, protected by exclusive right documentation, and attempts to introduce it into production (in cases where the technology owner is aware that he is committing a violation of intellectual rights or taking into account the facts proving the obviousness of this);

- assignment to products advertising materials, promotions, packaging and other signs attached to the product, storage of such products for their subsequent sale, attempts to sell them, import into the country and export abroad.

As actions aimed at introducing goods with illegally placed trademarks into civil circulation can be considered:

- submission of a customs declaration for such goods, with claiming them to customs regimes that suppose the use of goods in civil circulation in the customs territory;

-making a foreign trade deal, which subject is marking of goods with a trademark.

Violations in the field of intellectual property rights cause large damage not only to right holders and consumers of products, but also to the interests of the state on the whole, threatening its economy and national security.

Customs officials play an important role in controlling the international trade with goods containing intellectual property. First of all, this is the protection of intellectual property rights when these goods cross the customs border of the EAEU. The current mechanism of protection the intellectual property used by customs officials is the main obstacle for counterfeit goods to enter into the customs territory of the Eurasian Economic Union.

The use of intellectual property technologies without proper rights has become widespread among both developing and developed countries [1]. Therefore, in addition to controlling the customs value in relation to goods containing intellectual property, the customs authorities apply measures to protect the rights to intellectual property.

Problems of administrative and legal protection of intellectual property rights were studied in the works of D.B. Danilova, D.E. Salnova, A.P. Sergeeva, A.E. Filimonova and others. Certain aspects of the protection of intellectual property rights by the customs authorities were highlighted by V.V. Astanin, O. M. Ashurkov, A.G. T.I. Fomina, S.N. Shurygin, E.V. Yuryeva and others.

There is no scientific works of foreign authors about the organization of the customs authorities' activities in the field of protection of intellectual property rights in the international citation databases. In the countries of the European Union informative brochures have been created to explain the specifics of moving goods containing intellectual property objects across the customs border. However, the scientific works of scientists in this research area are not available to everyone.

The relevance of the research topic is determined by the need to study the problems of cross-border movement of goods containing objects of intellectual property, as well as the need to search and develop recommendations for improving customs mechanisms for suppressing economic offenses in this area. 
The aim of the study is a comprehensive analysis of the customs regulation system of the goods containing intellectual property cross-border movement in the context of Eurasian integration.

Protection of intellectual property rights is one of the priorities to form a single market for digital intellectual property in the EAEU [2].

In 2011 the EAEU Interstate Council for the Protection and Protection of Intellectual Property Rights was created, which activity is related not only to issues of industrial property rights, but also to issues of copyright and related with it rights. The functions of the council include, first of all, coordination of joint activity of the member states to the Agreement to improve legal protection and mechanisms for the protection of intellectual property rights, the development of scientific and technical cooperation and the realization of joint actions to prevent, detect and suppress violations in the field of intellectual property. Besides, the exchange of legislative, regulatory, methodological and other information is reckoned on.

A common thing for countries-members of the Eurasian Economic Union in the field of customs protection of intellectual property rights is the consolidation at the legislative level of provisions on national customs registers of intellectual property rights as a mechanism of customs control. Within the framework of the Common Economic Space of the EAEU at the supranational legislative level rules and special application forms of a right holder about applying protective rights to intellectual property have been created for customs protection. The movement of goods containing intellectual property objects across the customs borders of the EAEU is provided on a general basis, but due to its peculiarities, there must be following documents: declaration for goods; documents confirming the transfer of rights to intellectual property objects; documents confirming the introduction of goods marked with a trademark into civil circulation in the customs territory of the EAEU with the agreement of the copyright holder.

According to the provisions of the EAEU Customs Code [3] and Federal Law No. 289FZ "On Customs Regulation in the Russian Federation and on Amending Certain Legislative Acts of the Russian Federation" [4], the Federal Customs Service (hereinafter FCS) of Russia maintains the Customs Register of Intellectual Property Objects (hereinafter - CRIPO). This register contains information about objects of copyright, objects of related rights, trademarks, service marks and appellations of origin of products. Due to it, the Federal Customs Service of Russia takes measures that stop release of the goods. CRIPO is national. It is formed on the basis of copyright holders' statements. The register was created to the check products that come from abroad to the territory of the Russian Federation.

The customs authorities are empowered to ensure control over the observance of intellectual property owners rights, in particular, through documentary and actual control. Document control includes verification of information indicating the presence of intellectual property objects in the declared goods transported across the customs border, which are contained in the supply agreement, as well as in other customs documents.

The customs authorities of the EAEU member states take measures to protect intellectual property rights provided for in Article 124 of the EAEU Customs Code [3] about placing goods under customs procedures, with the exception of placing goods under the customs procedure for customs transit, the customs procedure for destroying, as well as a special customs procedure. Measures to protect intellectual property rights are not applied by customs authorities in relation to goods transported across the customs border: by individuals for personal use, including those sent to their address in international mail; according to the customs transition procedure; diplomatic representations, consular offices, other official representations of foreign states, international organizations, stuff of these representations, establishments and organizations for official and personal usage and etc. 
Customs regulation in terms of ensuring the protection of intellectual property rights is carried out in the following areas:

- maintaining the customs register of intellectual property objects on the basis of applications from copyright holders, incl. inclusion, exclusion of objects of intellectual property from the Register, making changes and additions to it;

- customs control, incl. control after the release of goods, in order to identify violations of customs and other legislation;

- monitoring the movement of goods containing objects of intellectual property;

- detection, prevention and suppression of administrative offenses and crimes in the field of intellectual property, referred by national law to the competence of customs authorities;

- operational-search activity of customs authorities in the field of activity to protect intellectual property rights in accordance with the procedure established by national law;

- interdepartmental cooperation on the issues of customs protection of intellectual property rights with authorized state bodies;

- international cooperation in the field of customs protection of intellectual property rights within the EAEU and WTO; [1].

- protection against unfair competition in the customs protection of intellectual property

Customs protection of intellectual property in the cross-border movement of goods is carried out by customs authorities on the basis of interdepartmental cooperation with other authorized state bodies, within the framework of their competence and powers established by the national legislation of the EAEU member states.

Within the framework of the WTO, international cooperation in the field of customs protection of intellectual property rights is carried out on the basis of the Agreement on Trade Aspects of Intellectual Property Rights. If the rightholder of intellectual property objects is the state, customs protection of rights to such objects is provided in cases of their entry into the Register and within the framework of the "ex officio" procedure (the customs authorities, without the owner's statement, check goods for any violations in moving them).

For the effective protection of national economic interests, rights and legitimate interests of right holders some special measures can be taken to limit intellectual property rights according to the national legislation of the EAEU member states, recognized principles and norms of international law, international treaties, etc.

In case of intruduction of restrictive measures by the national government according to esteblished by law information is sent to the customs authorities about intellectual property objects, that are abandoned and restricted to use in import / export. At the same time, the customs authorities prohibit the import of goods containing objects of intellectual property included in the sanctions list, regardless of whether these objects are included in CRIPO.

Considering the problem of control and development of methods to combat illegal use of intellectual property by moving it across the customs border of the EAEU it is necessary to consider the issue of control of Internet commerce. Every year, the interactions of humanity are increasingly moving into the electronic environment. This has become especially relevant during the COVID-19 global pandemic. The schemes for the import and sale of counterfeit goods, the share of such products being imported through the channels of international mail is increasing are changing actively. The logistics of the operations causes an increase in the latency of such crimes and administrative offenses: actually a trade transaction, when goods from a closed warehouse through a delivery service arrive directly to the buyer, falls out of the field of traditional forms of control and operational-search measures established by the authorized bodies. In this regard, it is obvious that there is a need to change approaches to the identification and suppression of offenses and crimes in 
the field of intellectual property, it is necessary to develop modern methods of struggle, possibly to expand the powers of regulatory bodies, improve legislation.

In the field of violations of intellectual property rights on the Internet, there is an effective mechanism for blocking Internet resources from which counterfeit content is distributed, confirmed by the practice of the Russian Federation, passing by traditional forms of influencing the distributor by bringing to administrative and (or) criminal liability. In order to develop this area further, it is necessary to search for optimal mechanisms of interaction between trading Internet platforms and trading Internet aggregators with copyright holders [1]. A new type of service should be developed for copyright holders and regulatory authorities - screening of Internet commerce to identify possible sources of distribution of counterfeit goods and content, researching the methods to organize customs control of international mail in order to identify illegal intellectual property objects usage.

Another way to control Internet commerce can be the development of a modern technology for the joint processing of international mail correspondence by mail and customs authorities. By the way, a unified informative system should be used to ensure that the customs authorities can collect and use information about recipient of the Internetparcels. Formation of a "green corridor" by ensuring the possibility of providing the customs authorities with preliminary information on ordering goods in a foreign online store. Most international Internet-parcels, during processed by mail of the departure country, are supplied with an international dispatch number to track the movement of the parcel. It is necessary to create an information service based on the informative system of the customs service, allowing the interested person to inform the customs authorities of the shipment number and a link to the order page of the goods, which contains an image and description (for its identification) after completing the purchase of goods in a foreign online store. This will allow the customs authority, when processing this Internet parcel, to automatically find out about the presence of information previously submitted by the recipient and to conduct automated control of the legality of the use of intellectual property objects. The proposed methodology complies with the provisions of the Strategy for the Development of the Customs Service until 2030, one of the directions of which is to promote the development of international trade and increase the quality of customs administration. on which there is an image and a description (for its identification). This will allow the customs authority, when processing this Internet parcel, to automatically find out about the presence of information previously submitted by the recipient and to conduct automated control of the legality of the use of intellectual property objects. The proposed methodology complies with the provisions of the Strategy for the Development of the Customs Service until 2030, one of the directions of which is to promote the development of international trade and increase the quality of customs administration. on which there is an image and a description (for its identification). This will allow the customs authority, when processing this Internet parcel, to automatically find out about the presence of information previously submitted by the recipient and to conduct automated control of the legality of the use of intellectual property objects. The proposed methodology complies with the provisions of the Strategy for the Development of the Customs Service until 2030, one of the directions of which is to promote the development of international trade and increase the quality of customs administration. when processing this Internet parcel, automatically learn about the presence of information previously submitted by the recipient and conduct automated control of the legality of the use of intellectual property objects. The proposed methodology complies with the provisions of the Strategy for the Development of the Customs Service until 2030, one of the directions of which is to promote the development of international trade and increase the quality of customs administration. when processing this Internet parcel, automatically learn about the presence of information previously submitted by the recipient and conduct automated control of the legality of the 
use of intellectual property objects. The proposed methodology complies with the provisions of the Strategy for the Development of the Customs Service until 2030, one of the directions of which is to promote the development of international trade and increase the quality of customs administration.

The development of Eurasian integration and formation revealed the absence of a unified legal regulation in matters of legal protection of the rights of copyright holders to trademarks in the member countries of the Eurasian Economic Union. In this regard, the problem of the need to unify a number of branches of legislation of the EAEU member states in the context of a common customs and economic space is still actual.

It is a common rule to all EAEU countries that the rights to intellectual property objects do not depend on ownership and other property rights to a material medium (thing) in which the corresponding result or means are expressed; the transfer of ownership of a thing does not entail the transfer or granting of intellectual rights to the result of intellectual activity or to the means of individualization expressed in this thing. However, the national legislation of the EAEU countries in relation to information and intellectual property contains fundamental differences between classification as objects of civil rights and as in their civil law turnover, which contradicts the real interests of national economies and business communities.

As a result of a comparative legal analysis, it was revealed that there are serious differences in legal regulation in the field of intellectual property within the five EAEU countries, which is an obstacle to the formation of common markets within the framework of Eurasian integration. Further development of the national legislation of the member states of the Eurasian Economic Union should be based on common principles and be carried out in a general direction.

An effective method of increasing the level of protection of intellectual property rights is the direct involvement of owners of intellectual property objects in cooperation with customs authorities. The effectiveness of measures taken by the customs authorities to combat intellectual property offenses largely depends on the availability of feedback and information support from right holders. This is due to the fact that it is the copyright holders who have the most relevant information about the violation of their rights and legitimate interests. It should be noted that the legislation of the Republic of Armenia does not provide for the possibility of customs authorities to suspend goods suspected of infringing intellectual property rights on their own, making charges in criminal cases or cases of administrative offenses is possible only if there is a corresponding application from the copyright holders of rights to trademarks.

The effectiveness of the protection of intellectual property rights in close cooperation with copyright holders is confirmed by practice and is highly appreciated by a number of companies that include their trademarks and brands in customs registers. In Russian law enforcement practice, it is not uncommon for the owner of intellectual property to ignore the requests of the customs authorities of the EAEU, since it does not want to participate in litigation. As a rule, this is connected with the fact that copyright holders believe that the legal costs incurred by them will significantly exceed the potential damage. Also, refusal to cooperate may be associated with the ignorance of copyright holders, the desire to hide the facts of product counterfeiting, participation in illegal "gray" schemes of production, or import of goods, etc.

The effectiveness of the protection of intellectual property objects and their right holders is also affected by the lack of awareness of the customs authorities about the nature of intellectual property objects. During the expertise of goods containing objects of intellectual property, there is a problem of obtaining an original sample for research, since the product is produced by collections and cannot be provided to every expert. In such cases, the copyright holder provides a description of the original product. However, in 
practice, copyright holders provide only a description of the signs that do not fit to the original. It creates some problems in the work of an expert, since there may be more discrepancies or they may be other. In the list of inconsistencies firstly highlighted things are the lack of cargo packaging or improper appearance, if there is any, the wrong placement of trademarks, violating certain rules consolidated in the guide of toy manufacturers in a branded style. Cargo packaging is not provided to the customs expert even if it is available. An analysis of the practice of conducting expert examinations showed that objects registered in CRIPO do not always completely coincide with the designations placed on the original products. This circumstance makes it difficult to conduct a study to determine the similarity. Moreover, as a unified designation the objects of intellectual property can be registered in Russian and in English languages. If it is necessary to solve a question about recognizing the goods as counterfeit, the court may not accept the expert's opinion as evidence, if no comparison has been made with the original products, and the right holder of the trademark or his representative did not provide the relevant information. As practice shows, many international trademark companies are not familiar with the mechanism for protecting the rights of intellectual property owners in the EAEU, which prevents close interaction and does not allow customs authorities to secure the EAEU and Russian markets, including from counterfeiting.

Thus, insufficiently effective interaction between customs authorities and right holders, in practice, significantly slows down the process of obtaining information and conducting effective customs control.

The use of electronic technologies to accelerate the registration of intellectual property objects in CRIPO will have a beneficial effect on the level of protection of copyright holders, and will help fill in the database of intellectual property images. Also, participants in foreign trade will have the opportunity to receive information about the status of intellectual property in the system of customs authorities directly to their mobile device.

In conclusion, it is necessary to revise and optimize the existing systems of controlling the movement of intellectual property objects across the customs border of the EAEU, as well as introduce new technologies that will speed up the process of registering intellectual property objects in customs systems. This step will help to increase the level of protection of intellectual property objects and simplify the process of its commercial relocation. Another priority area for improving the interaction of customs authorities with law enforcement agencies and international organizations is the introduction of modern integrated informative digital technologies.

The proposed directions for improving the system of customs regulation of cross-border movement of goods containing intellectual property objects in the context of Eurasian integration can help increase the investment attractiveness of innovative activity carried out within the EAEU, the implementation, as well as the creation and commercialization of intellectual property.

\section{References}

1. I.V. Minakova, T.N. Bukreeva, O.I. Soloduhina, O.G. Timofeeva CBU: International Conference on Innovations in science and Education, P. 356-360, (2018)

2. Eurasian Economic Union Treaty, (2014)

3. Customs Code of the Eurasian Economic Union, (2018)

4. Federal Law No. 289-FZ «On Customs Regulation in the Russian Federation and on Amending Certain Legislative Acts of the Russian Federation», (2018) 